\title{
Dithienothiazine Copolymers - Synthesis and Electronic Properties of Novel Redox-Active Fluorescent Polymers
}

\author{
Jennifer $\mathrm{Nau}^{\mathrm{a}}$ (D) \\ Thomas J. J. Müller*a \\ a Institut für Organische Chemie und Makromolekulare Chemie, Heinrich-Heine- \\ Universität Düsseldorf, Universitätsstraße 1, D-40225 Düsseldorf, Germany \\ Thomas]J.Mueller@uni-duesseldorf.de
}

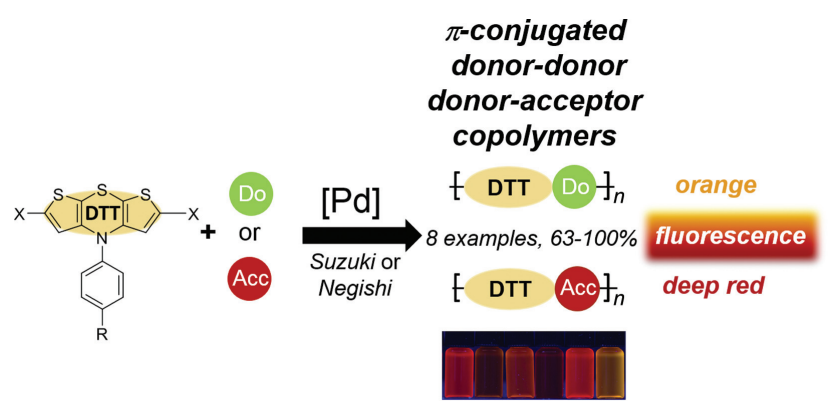

moieties have aroused interest for use in plastic electronics. $^{7}$

As donor components, ensuring high lying HOMO energies and generation of stable radical cations upon oxidation with triarylamines ${ }^{8}$ and thiophene motifs ${ }^{9}$ have received significant prominence as hole transporters. Furthermore, $S, N$-containing tricycles, such as 3,7-disubstituted phenothiazines, exhibit fully reversible one-electron oxidations at low potentials, ${ }^{10}$ extraordinarily stable radical cations, ${ }^{11}$ and pronounced luminescence. For instance, organic light-emitting diodes ${ }^{12}$ as well as redox switchable luminophores ${ }^{13}$ have been developed based on oligomeric and polymeric phenothiazines.

Just very recently, we have introduced dithieno[1,4] thiazines, electron-density enriched congeners of phenothiazines, ${ }^{14}$ which even have lower oxidation potentials with higher radical cation stability, as novel types of donors for organic chromophores and electrophores. ${ }^{15}$ The paramount practical advantage of dithieno[1,4]thiazines over phenothiazines is their ready functionalization in the $\alpha, \alpha^{\prime}-$ positions of the thieno cores. Based upon versatile transformations by lithiation-electrophilic trapping sequences, ${ }^{16}$ halogenated and organometallic build blocks became accessible, which were employed to the efficient synthesis of dithienothiazine dimers, trimers and homopolymers. ${ }^{17}$ Here, we report on the synthesis and characterization of dithienothiazine copolymers based upon Suzuki and Negishi polymerization as well as on the electronic properties of these polymers.

\section{Results and Discussion}

\section{Synthesis and Polymer Characterization}

For ensuring high solubility in common organic solvents, we decided to introduce $p$-phenoxy to an aliphatic swallow tail in the 4H-dithieno[2,3-b:3',2'-e][1,4]thiazine 1 


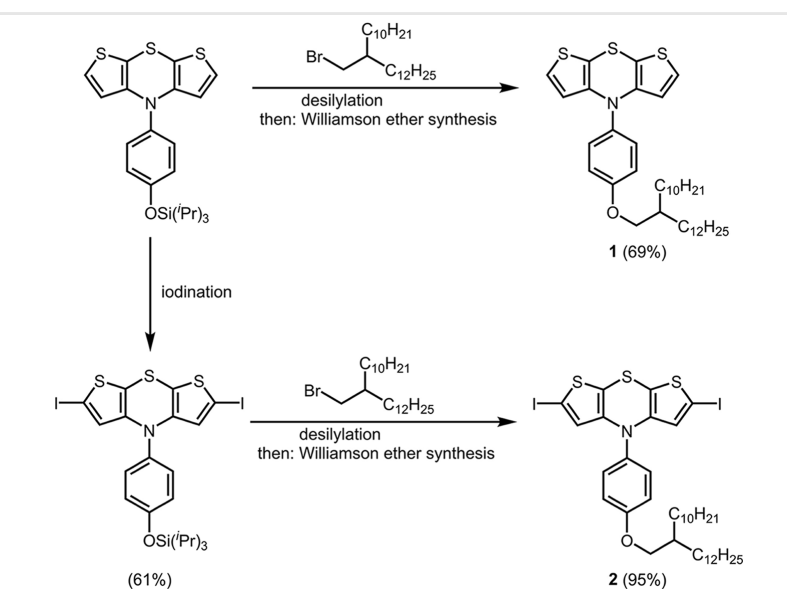

Scheme 1 Synthesis of syn,syn-dithienothiazine starting materials 1 and 2 .

(conveniently we will abbreviate this unit as syn,syndithienothiazine since the sulfur atoms are in a syn-syn relationship). Starting with a TIPS-protected precursor that is obtained in good yield via $(5+1)$-Buchwald-Hartwig cyclization, compound $\mathbf{1}$ is directly formed by one-pot fluoride-induced desilylation and Williamson ether synthesis, whereas for the diiodo derivative $\mathbf{2}$ the TIPS-protected precursor is first selectively iodinated followed by one-pot desilylation-etherification synthesis (Scheme 1). ${ }^{17}$

With dithienothiazine monomers $\mathbf{1}$ and $\mathbf{2}$ in hand, we synthesized dithienothiazine copolymers $\mathbf{4}$ by Suzuki polymerization of diiodo dithienothiazine $\mathbf{2}$ and (hetero) aryl bis(boronate) $\mathbf{3}$ (Scheme 2) and by Negishi polymerization in situ dilithiated dithienothiazine $\mathbf{1}$ and diiodo (hetero)arene $\mathbf{5}$ (Scheme 3) as dark red to black solids or resins in good to excellent yields.

The novel dithienothiazine copolymers 4 were characterized by IR spectroscopy and gel permeation chromatography (GPC). ${ }^{18}$ For the THF-soluble copolymers $\mathbf{4 a}, \mathbf{4 b}, \mathbf{4 c}$, 4e, 4f, and $4 \mathbf{h},{ }^{1} \mathrm{H}$ and ${ }^{13} \mathrm{C}$ NMR spectra were recorded showing broad, poorly resolved signals, yet, showing approximate integral ratios that support the corresponding proposed ligation. For some polymers prepared by the Negishi polymerization protocol, residual TMEDA stemming from the lithiation of monomer $\mathbf{1}$, which cannot be completely removed by multiple suspension-sonication cycles and extensive high vacuum drying, is discernable in the NMR spectra. MALDI TOF mass spectra rather revealed several molecular peaks for short oligomers with various end groups, such as pinacolyl boryl or iodo substituents.

GPC in THF with polystyrene as a standard ${ }^{19}$ allows determining the number average molecular weight $\left(M_{\mathrm{n}}\right)$, the weight average molecular weight $\left(M_{\mathrm{w}}\right)$, the molecular weight of the detector signal maximum $\left(M_{\mathrm{p}}\right)$ as well as the dispersity $\bigoplus_{\mathrm{M}}=M_{\mathrm{w}} / M_{\mathrm{n}}$ and the degree of polymerization DP. For the interpretation the globular structure of

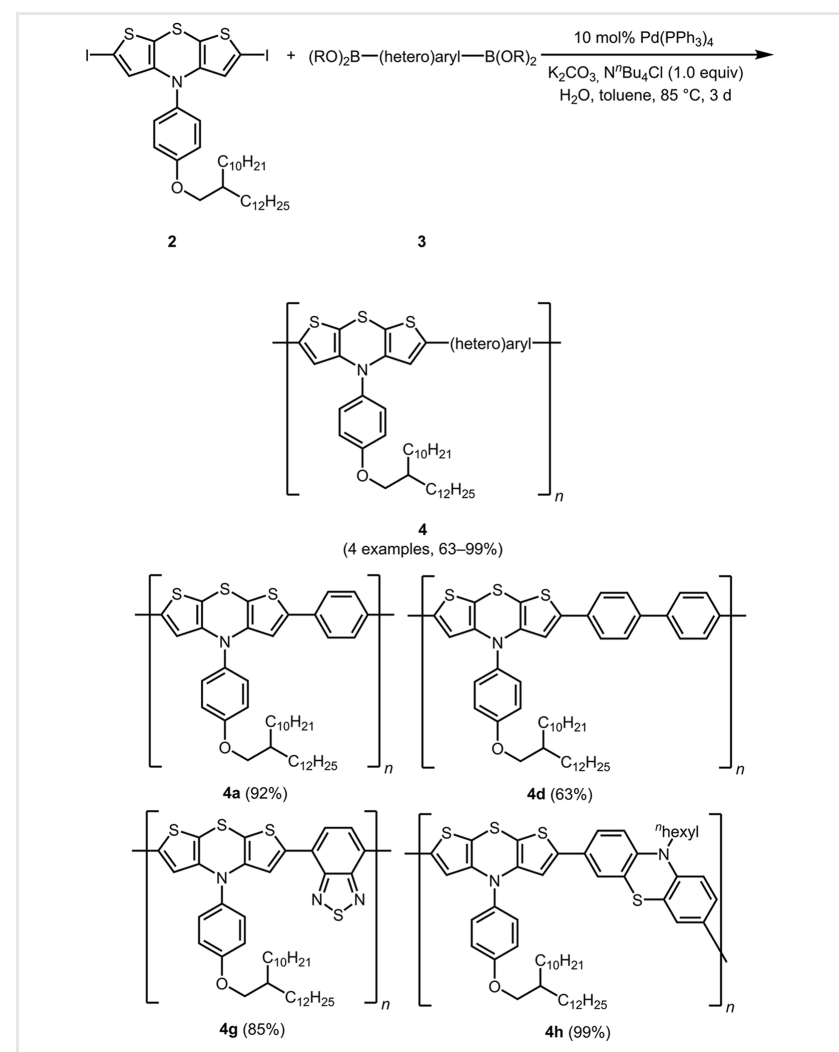

Scheme 2 Suzuki polymerization synthesis of dithienothiazine copolymers 4.

polystyrene chains in comparison to the bacillary nature of poly(dithienothiazines) has to be taken into account, overestimating the molecular weights of poly

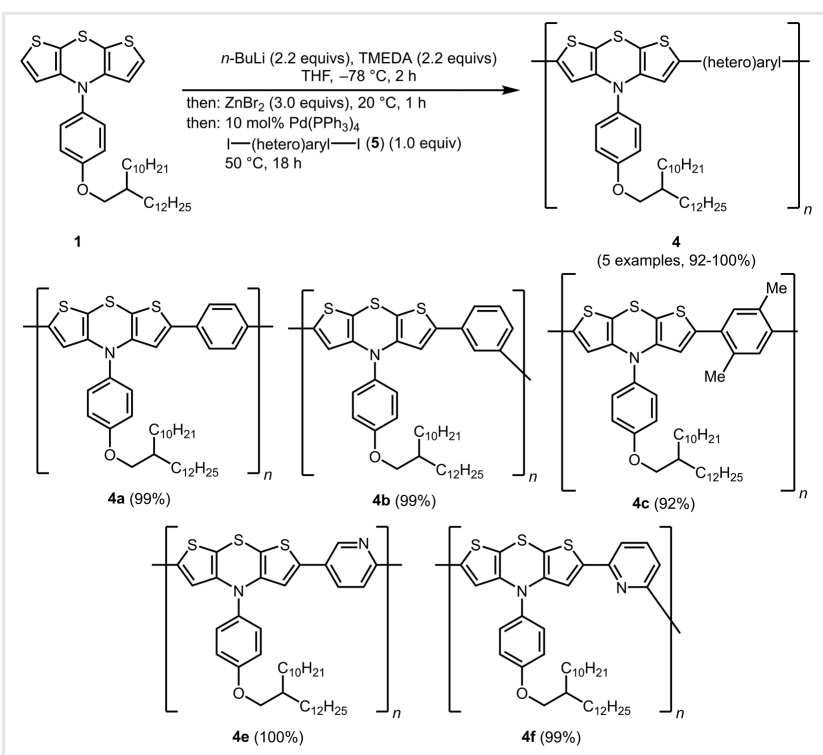

Scheme 3 Negishi polymerization synthesis of dithienothiazine copolymers 4 . 
Table 1 Molecular weight distributions of the copolymers 4 according to GPC (eluent THF, flow rate $1 \mathrm{~mL} / \mathrm{min}, T=293 \mathrm{~K}$ )

\begin{tabular}{|c|c|c|c|c|c|c|}
\hline \multirow[t]{2}{*}{ Polymer } & \multicolumn{4}{|c|}{ Molecular weight [Da] } & \multirow{2}{*}{$\begin{array}{l}\text { Dispersity } \\
\bigoplus_{\mathrm{M}}{ }^{\mathrm{e}}\end{array}$} & \multirow{2}{*}{$\begin{array}{l}\begin{array}{l}\text { Degree of } \\
\text { polymerizatio }\end{array} \\
\mathrm{DP}^{\mathrm{f}}\end{array}$} \\
\hline & $M_{0}{ }^{\mathrm{a}}$ & $M_{\mathrm{n}}^{\mathrm{b}}$ & $M_{\mathrm{w}}{ }^{\mathrm{c}}$ & $M_{p}^{d}$ & & \\
\hline $4 a^{9}$ & 714.1 & $3.76 \cdot 10^{3}$ & $6.22 \cdot 10^{3}$ & $9.47 \cdot 10^{3}$ & 1.65 & 8.7 \\
\hline $4 a^{h}$ & & $5.93 \cdot 10^{3}$ & $8.96 \cdot 10^{3}$ & $6.74 \cdot 10^{3}$ & 1.51 & 12.5 \\
\hline $4 b^{h}$ & 714.1 & $3.74 \cdot 10^{3}$ & $6.14 \cdot 10^{3}$ & $1.64 \cdot 10^{3}$ & 1.64 & 8.6 \\
\hline $4 c^{h}$ & 742.2 & $4.24 \cdot 10^{3}$ & $7.27 \cdot 10^{3}$ & $1.78 \cdot 10^{3}$ & 1.71 & 9.8 \\
\hline $4 d^{9}$ & 790.2 & $1.04 \cdot 10^{4}$ & $1.65 \cdot 10^{4}$ & $1.61 \cdot 10^{4}$ & 1.59 & 20.9 \\
\hline $4 e^{h}$ & 715.1 & $8.41 \cdot 10^{3}$ & $1.41 \cdot 10^{4}$ & $1.72 \cdot 10^{4}$ & 1.68 & 19.7 \\
\hline $4 f^{h}$ & 715.1 & $4.44 \cdot 10^{3}$ & $6.02 \cdot 10^{3}$ & $3.79 \cdot 10^{3}$ & 1.35 & 8.4 \\
\hline $4 \mathbf{g}^{\mathrm{g}}$ & 772.2 & $2.46 \cdot 10^{3}$ & $2.95 \cdot 10^{3}$ & $2.46 \cdot 10^{3}$ & 1.20 & 3.8 \\
\hline $4 h^{9}$ & 919.5 & $1.01 \cdot 10^{4}$ & $1.37 \cdot 10^{4}$ & $1.50 \cdot 10^{4}$ & 1.36 & 14.9 \\
\hline
\end{tabular}

${ }^{a} M_{0}$ : molecular weight of the repeating unit.

${ }^{\mathrm{b}} M_{\mathrm{n}}$ : number average molecular weight.

${ }^{c} M_{\mathrm{w}}$ : weight average molecular weight.

${ }^{\mathrm{d}} M_{\mathrm{p}}$ : molecular weight of the detector signal maximum.

${ }^{\mathrm{e}} \bigoplus_{\mathrm{M}}=M_{\mathrm{w}} / M_{\mathrm{n}}$ : dispersity.

${ }^{\mathrm{f}} \mathrm{DP}=M_{\mathrm{w}} / M_{0}$ : degree of polymerization.

'Suzuki polymer synthesis.

${ }^{\mathrm{h}}$ Negishi polymer synthesis.

(dithienothiazines). The GPC data of the copolymers $\mathbf{4}$ are summarized in Table 1.

The average molecular weights of the dithienothiazine copolymers 4 fall into a range between 3000 and 18000 $\mathrm{g} / \mathrm{mol}$. In the GPC traces of copolymers $\mathbf{4 a}, \mathbf{4 b}, \mathbf{4 c}, \mathbf{4 g}, \mathbf{4 e}$, and 4f, lower oligomers are also visible (Figure 1).
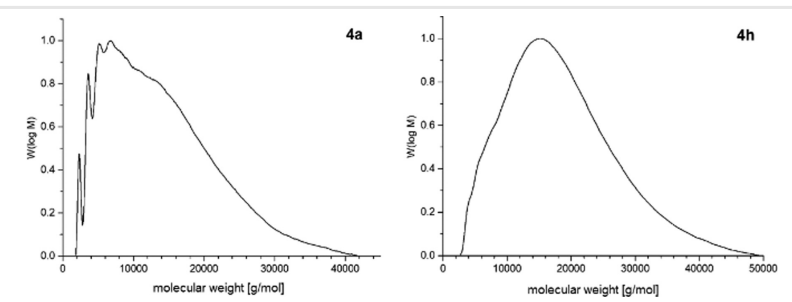

Figure 1 Representative GPC traces of copolymers $\mathbf{4 a}$ (left) and $\mathbf{4 h}$ (right) (eluent THF, flow rate $1 \mathrm{~mL} / \mathrm{min}, T=293 \mathrm{~K}$ ).

\section{Thermal Properties}

The copolymers $\mathbf{4 a}$ and $\mathbf{4 d - h}$ were furthermore investigated by thermogravimetric analysis for obtaining an insight into their thermal stability (Table 2). Our interest was focused on the stability of the N-substituent towards thermal cleavage. After extrusion of solvent residues above $100^{\circ} \mathrm{C}$, all investigated copolymers 4 are thermally stable up to a temperature of $205{ }^{\circ} \mathrm{C}$. While copolymer $4 \mathbf{f}$ starts to decompose at $205{ }^{\circ} \mathrm{C}$, copolymer $\mathbf{4 d}$ only starts to decompose above $275{ }^{\circ} \mathrm{C}$. In the range of 350 to $395{ }^{\circ} \mathrm{C}$, the pyrolytic cleavage of the solubilizing swallowtail
Table 2 Thermogravimetric analysis of copolymers 4

\begin{tabular}{llllll}
\hline \multicolumn{5}{l}{ Decomposition } \\
\hline Copolymer & $\begin{array}{l}\text { Start } \\
{\left[{ }^{\circ} \mathrm{C}\right]}\end{array}$ & $\begin{array}{l}\text { Maximum } \\
{\left[{ }^{\circ} \mathrm{C}\right]}\end{array}$ & $\begin{array}{l}\text { End } \\
{\left[{ }^{\circ} \mathrm{C}\right]}\end{array}$ & $\begin{array}{l}\text { Weight } \\
\text { loss [\%] }\end{array}$ & $\begin{array}{l}\text { Molecular mass } \\
\text { percentage of } \\
\text { the swallowtail [\%] }\end{array}$ \\
\hline $\mathbf{4 a}$ & 235 & 360 & 495 & 47.12 & 47.1 \\
$\mathbf{4 d}$ & 275 & 365 & 500 & 40.97 & 42.6 \\
$\mathbf{4 e}$ & 250 & 395 & 485 & 50.60 & 47.0 \\
$\mathbf{4 f}$ & 205 & 350 & 480 & 48.05 & 47.0 \\
$\mathbf{4 g}$ & 220 & 380 & 450 & 43.53 & 43.6 \\
$\mathbf{4 h}$ & 230 & 380 & 450 & 44.61 & $45.9^{\mathrm{a}}$ \\
\hline
\end{tabular}

aWith concomitant cleavage of the phenothiazine's hexyl chain.

proceeds. This is indicated, depending on the corresponding copolymer 4, by a loss of weight between 40.97 and $50.60 \%$, in accordance with the proportional molecular weight of the swallowtail. At temperatures between 450 and $500{ }^{\circ} \mathrm{C}$, the pyrolytic cleavage of the swallowtail ceases.

\section{Electronic Properties}

The electronic properties of the dithienothiazine copolymers 4 were investigated by cyclic voltammetry and absorption and emission spectroscopy. Upon comparison of the cyclic voltammograms of copolymers $\mathbf{4}$ with the $\mathrm{CV}$ of the previously reported dithienothiazine homopolymer, ${ }^{17}$ a similar behavior becomes apparent. Only broad oxidation and reduction waves are displayed, which cannot be elaborated further (Figure 2). 

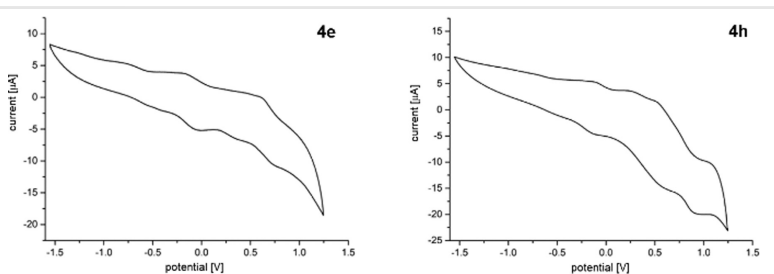

Figure 2 Cyclic voltammograms of dithienothiazine copolymers $4 \mathrm{e}$ (left) and 4h (right) (recorded in $\mathrm{CH}_{2} \mathrm{Cl}_{2}, T=293 \mathrm{~K}, 0.1 \mathrm{~m}$ electrolyte $\left[{ }^{n} \mathrm{Bu}_{4} \mathrm{~N}\right]\left[\mathrm{PF}_{6}\right] ; v=100 \mathrm{mV} / \mathrm{s}$; Pt working electrode, $\mathrm{Ag} / \mathrm{AgCl}$ reference electrode and Pt counter electrode).

The solutions of copolymers $\mathbf{4 a}, \mathbf{4 b}, \mathbf{4 c}, \mathbf{4 e}, \mathbf{4 f}$, and $\mathbf{4 h}$ are orange to red under daylight and they fluoresce with orange to deep red color under the handheld UV lamp (Figure 3).

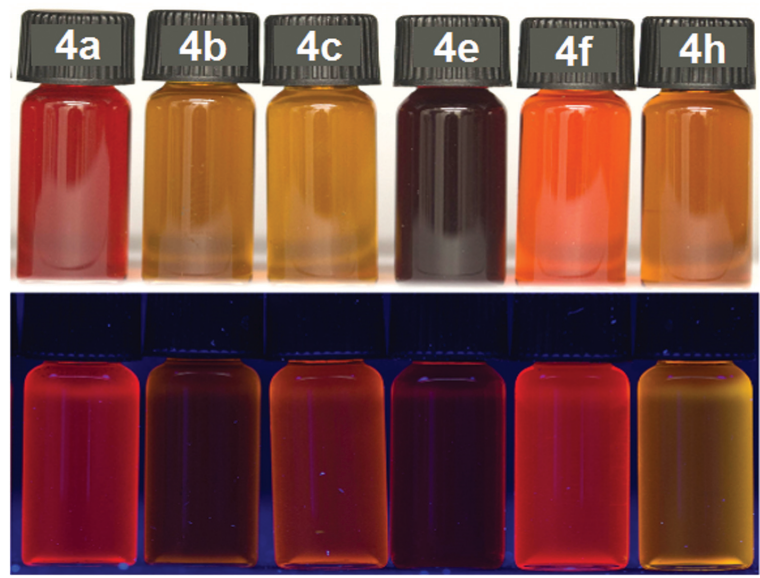

Figure 3 Solutions of selected dithienothiazine copolymers 4 (recorded in $\mathrm{CH}_{2} \mathrm{Cl}_{2}, T=293 \mathrm{~K}, \mathrm{c}(\mathbf{4})=10^{-6} \mathrm{M}$, under daylight (top) and under the handheld UV lamp, $\lambda_{\text {exc }}=365 \mathrm{~nm}$ ).
Absorption and emission spectra of the dithienothiazine copolymers $\mathbf{4}$ were recorded in dichloromethane or in THF, depending on the solubility (Table 3, Figure 4). For copolymer

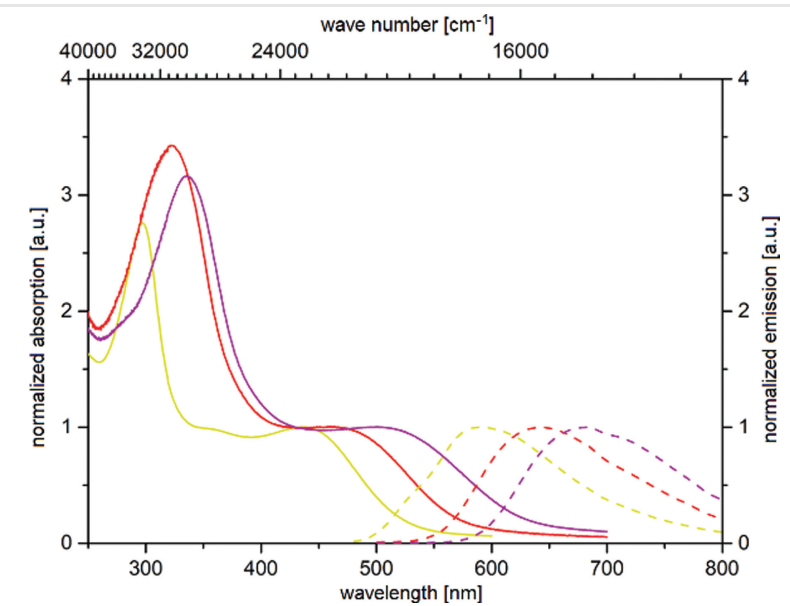

Figure 4 Normalized absorption (solid lines) and emission (dashed lines) spectra of copolymers $\mathbf{4 a}$ (red lines), $\mathbf{4 e}$ (magenta lines), and $\mathbf{4 h}$ (yellow lines) (absorption spectra recorded in $\mathrm{CH}_{2} \mathrm{Cl}_{2}, T=293 \mathrm{~K}, \mathrm{C}$ (4) $=10^{-5} \mathrm{M}$; emission spectra recorded in $\mathrm{CH}_{2} \mathrm{Cl}_{2}, T=293 \mathrm{~K}, \mathrm{C}$ (4) $=10^{-5} \mathrm{~m}, \lambda_{\text {exc }}=470 \mathrm{~nm}$ ).

4a, the absorption bands essentially are at the same energy in both solvents, dichloromethane and THF. Only the emission maximum experiences a slight redshift upon changing from THF to the polar solvent dichloromethane.

All copolymers 4 possess two characteristic absorption bands, the higher energy absorptions fall into a range from 291 to $336 \mathrm{~nm}$ and lower energy longest wavelength absorption band appears in a broad range from 436 to

Table 3 Selected absorption and emission data of dithienothiazine copolymers 4

\begin{tabular}{llllll}
\hline & Solvent & $\lambda_{\text {max,abs }}[\mathrm{nm}]\left(\varepsilon\left[\mathrm{L} \mathrm{mol}^{-1} \mathrm{~cm}^{-1}\right]\right)^{\mathrm{a}}$ & $\lambda_{\text {max,em }}[\mathrm{nm}]^{\mathrm{b}}$ & Stokes shift $\Delta_{\tilde{\nu}}\left[\mathrm{cm}^{-1}\right]^{\mathrm{c}}$ & $\begin{array}{l}\Delta E_{\text {opt(HomO-LUMO) }}\left(E_{0-0}\right)^{\mathrm{d}} \\
{[\mathrm{eV}(\mathrm{nm})]}\end{array}$ \\
\hline $\mathbf{4 a}$ & $\mathrm{CH}_{2} \mathrm{Cl}_{2}$ & $322(18100), 461(5300)$ & 643 & 6100 & $2.18(569)$ \\
$\mathbf{4 a}$ & $\mathrm{THF}$ & $322(22200), 461(6700)$ & 631 & 5800 & $2.21(562)$ \\
$\mathbf{4 b}$ & $\mathrm{CH}_{2} \mathrm{Cl}_{2}$ & $295(26300), 442 \mathrm{sh}(3600)$ & 608 & 6200 & $2.29(542)$ \\
$\mathbf{4 c}$ & $\mathrm{CH}_{2} \mathrm{Cl}_{2}$ & $291(21600), 437(4000)$ & 637 & 7200 & $2.24(553)$ \\
$\mathbf{4 d}$ & $\mathrm{THF}$ & $328(26200), 471(8700)$ & 628 & 5300 & $2.19(565)$ \\
$\mathbf{4 e}$ & $\mathrm{CH}_{2} \mathrm{Cl}_{2}$ & $336(21000), 501(6600)$ & 681 & 5300 & $2.03(610)$ \\
$\mathbf{4 f}$ & $\mathrm{CH}_{2} \mathrm{Cl}_{2}$ & $316(17600), 465(3400)$ & 640 & 5900 & $2.18(570)$ \\
$\mathbf{4 g}$ & $\mathrm{THF}$ & $300(21600), 747(11200)$ & - & - & - \\
$\mathbf{4 h}$ & $\mathrm{CH} \mathrm{Cl}_{2}$ & $297(42800), 436(15500)$ & 587 & 5900 & $2.40(516)$ \\
\hline
\end{tabular}

a Recorded at $T=293 \mathrm{~K}, c(4)=10^{-5} \mathrm{M}$.

becorded at $T=293 \mathrm{~K}, \mathrm{c}(\mathbf{4})=10^{-6} \mathrm{M}, \lambda_{\mathrm{exc}}=470 \mathrm{~nm}$

${ }^{\mathrm{c}} \Delta_{\tilde{\nu}}=\lambda_{\text {max }, \text { abs }}{ }^{-1}-\lambda_{\text {max }, \mathrm{em}^{-1}}\left[\mathrm{~cm}^{-1}\right]$.

${ }^{\mathrm{d}} E_{0-0}$ was determined at the intersection of the corresponding normalized absorption and emission bands. ${ }^{20}$ 
$747 \mathrm{~nm}$. Expectedly, an electron-withdrawing bridging unit, such as 2,5-pyridylene or 4,7-benzothiadiazolylene, causes a considerable bathochromic shift in comparison to electron neutral or electron-donating bridging units. Therefore, most blueshifted is the absorption band of the electron-rich dithienothiazine-phenothiazine copolymer $\mathbf{4 h}$.

Most distinctly, the emission maxima of the dithienothiazine copolymers 4 appear in a range from 587 to $681 \mathrm{~nm}$, again in agreement with the electronic nature of the bridging unit. In contrast to many simple dithienothiazines with 2,6diaryl substitution, which are only weakly luminescent, ${ }^{6 a}$ this novel type of low-band gap polymers is intensely luminescent with orange to deep red color. Furthermore, from the intersection of the absorption and emission spectra, the optical band gap $\Delta E_{\text {opt }}$ that corresponds to the $E_{0-0}$ transition ${ }^{20}$ can be estimated for the copolymers 4 , and lies in a range between 2.03 and $2.40 \mathrm{eV}$. Therefore, the dithienothiazine-2,5-pyridine copolymer $\mathbf{4 e}$ possesses the smallest and the dithienothiazine-phenothiazine copolymer $\mathbf{4 h}$ the largest band gap. Since the typical window for optical band gaps of organic semiconductors encompasses a range from 1.5 to $3.0 \mathrm{eV},{ }^{21}$ all these novel dithienothiazine copolymers qualify as low band gap semiconductors.

\section{Conclusions}

In summary, we have employed the previously published organometallic synthesis of dithienothiazine homopolymers and oligomers to the generation of dithienothiazine copolymers. Indeed, two complementary polymerizations, Suzuki polymerization and in situ lithiation-Negishi polymerization, were successfully probed to give a series of eight dithienothiazine copolymers in good to excellent yields. The dispersities and degrees of polymerization were determined by GPC measurements of the molecular weight distribution. The copolymers are remarkably stable with respect to thermal cleavage of the solubilizing side chains, which does not proceed up to $200{ }^{\circ} \mathrm{C}$. The copolymers are deep colored amorphous solids or resins that dissolve readily in organic solvents. The absorption and emission spectra not only reveal broad absorption bands in the visible, but also orange to deep red luminescence upon excitation with UV light. The determined optical band gaps qualify these novel copolymers as a new class of potential low band gap organic semiconductors. A more detailed treatment of the electronic structure of dithienothiazine-bridge-dithienothiazine models of the copolymers is currently underway.

\section{Experimental Section}

Reagents, catalysts, and solvents were purchased reagent grade and used without further purification. Mono- mers $\mathbf{1}$ and $\mathbf{2}$ were synthesized according to our previously published protocol. ${ }^{17}$ Bisboronate $\mathbf{3 d}$ was prepared according to our previously published protocol ${ }^{22}$ and bisboronate 3c was prepared from the corresponding 4,7-dibromobenzo[c] $[1,2,5]$ thiadiazole $^{23}$ by Miyaura coupling. ${ }^{24}$ Anhydrous THF was obtained from a drying system (MBraun systemMB-SPS-800) and toluene was dried over MS $3 \AA$ for at least $24 \mathrm{~h}$. The reaction progress was monitored qualitatively by using TLC silica gel $60 \mathrm{UV}_{254}$ sheets obtained by Macherey-Nagel GmbH \& Co. KG. The spots were detected with UV light at 254 and $365 \mathrm{~nm}$. The ${ }^{1} \mathrm{H}$ and ${ }^{13} \mathrm{C}$ NMR spectra were determined on a $600 \mathrm{MHz}$ NMR spectrometer. Chemical shifts $\delta$ are reported in ppm relative to the internal solvent signals of THF- $d_{8}\left({ }^{1} \mathrm{H} \delta 3.58,{ }^{13} \mathrm{C} \delta 67.6\right)$. By using DEPT-135 spectra the quaternary $\mathrm{C}, \mathrm{CH}, \mathrm{CH}_{2}$, and $\mathrm{CH}_{3}$ signals were assigned. Infrared spectra were recorded with neat compounds under attenuated total reflection and the intensities were characterized as strong ( $\mathrm{s})$, middle $(\mathrm{m})$, and weak $(w)$. The elemental analyses were carried out in the microanalytical laboratory of the Pharmazeutisches Institut, Heinrich-Heine-Universität Düsseldorf. Absorption and emission spectra were recorded in dichloromethane HPLC grade at $293 \mathrm{~K}$ on a Perkin Elmer UV/Vis/NIR Lambda 19 (absorption) and Hitachi F7000 (emission) spectrometer. The cyclic voltammetry experiments were performed under argon in dry and degassed dichloromethane at $293 \mathrm{~K}$ using a small-scale set-up with a three-electrode arrangement ( $2 \mathrm{~mm}$ platinum working electrode, platinum wire counter electrode, $\mathrm{Ag} / \mathrm{AgCl}$ reference electrode) with tetrabutylammonium hexafluorophosphate as the electrolyte. The oxidation potentials were determined against the internal standard decamethylferrocene $\left(E^{0 /+1}=-95 \mathrm{mV}\right)$. The potential of this standard was determined against ferrocene $\left(E^{0 /+1}=450 \mathrm{mV}^{25}\right)$.

\section{General Procedure for the Suzuki Polymerization (GP1)}

In an oven-dried Schlenk flask with a magnetic stir bar, a mixture of 4-(4-((2-decyltetradecyl)oxy)phenyl)-2,6-diiodo4H-dithieno[2,3-b:3',2'-e][1,4]thiazine (2) (357 mg, $0.40 \mathrm{mmol})$, diboronic acid/diboronate $3(0.40 \mathrm{mmol})$, tetrabutylammonium chloride $(111 \mathrm{mg}, 0.40 \mathrm{mmol})$, toluene $(16 \mathrm{~mL})$ and a saturated aqueous solution of potassium carbonate $(4 \mathrm{~mL}$ ) was degassed with argon for $20 \mathrm{~min}$ (for experimental details, see Table 4). Then, tetrakis(triphenylphosphane)palladium(0) (10 mol\%, $46.0 \mathrm{mg}, 0.04 \mathrm{mmol})$ was added to the reaction mixture and the reaction mixture was heated under an argon atmosphere at $85^{\circ} \mathrm{C}$ (oil bath) for $3 \mathrm{~d}$. After cooling to room temperature, water $(20 \mathrm{~mL})$ was added to stop the reaction. The organic layer was separated and the aqueous phase was extracted with dichloromethane $(3 \times 20 \mathrm{~mL})$. The combined organic layers were dried with 


\begin{tabular}{|c|c|c|}
\hline Entry & Diboronic acid/diboronate $\mathbf{3}$ & $\begin{array}{l}\text { Dithienothiazine } \\
\text { copolymer } \mathbf{4} \text { (yield) }\end{array}$ \\
\hline 1 & $66.0 \mathrm{mg}(0.40 \mathrm{mmol})$ of $3 \mathrm{a}$ & $272 \mathrm{mg}(92 \%)$ of $4 a$ \\
\hline 2 & $97.0 \mathrm{mg}(0.40 \mathrm{mmol})$ of $3 \mathbf{b}$ & $204 \mathrm{mg}(63 \%)$ of $4 \mathbf{d}$ \\
\hline $3^{\mathrm{a}}$ & $155 \mathrm{mg}(0.40 \mathrm{mmol})$ of $3 \mathrm{c}$ & $290 \mathrm{mg}(85 \%)$ of $\mathbf{4 g}$ \\
\hline 4 & $214 \mathrm{mg}(0.40 \mathrm{mmol})$ of $\mathbf{3 d}$ & $374 \mathrm{mg}(99 \%)$ of $4 \mathrm{~h}$ \\
\hline
\end{tabular}

Reaction time at $85^{\circ} \mathrm{C}$ for $4 \mathrm{~d}$.

anhydrous magnesium sulfate, filtered and the solvent was removed under reduced pressure to give the crude product 4 .

\section{General Procedure for the Negishi Polymerization (GP2)}

In an oven-dried Schlenk flask with a magnetic stir bar, a mixture of 4-(4-((2-decyltetradecyl)oxy)phenyl)-4Hdithieno[2,3-b:3',2'-e][1,4] thiazine (1) (192 mg, $0.30 \mathrm{mmol})$, TMEDA $(0.10 \mathrm{~mL}, 0.66 \mathrm{mmol})$, and dry THF $(6 \mathrm{~mL})$ under argon was cooled to $-78{ }^{\circ} \mathrm{C}$ (dry ice/acetone). Then, $n$-butyllithium in hexanes $(1.58 \mathrm{~m}, 0.42 \mathrm{~mL}$, $0.60 \mathrm{mmol}$ ) was added dropwise over $10 \mathrm{~min}$ and stirring at $-78{ }^{\circ} \mathrm{C}$ was continued for $2 \mathrm{~h}$. Then, a solution of freshly dried zinc bromide (203 $\mathrm{mg}, 0.90 \mathrm{mmol}$ ) in dry THF ( $1 \mathrm{~mL})$ was added to the reaction mixture, which was then allowed to come to room temperature. After stirring at room temperature for $1 \mathrm{~h}$, tetrakis(triphenylphosphane)palladium(0) $(10 \mathrm{~mol} \%, 35.0 \mathrm{mg}, 0.03 \mathrm{mmol})$ and diiodo(hetero)arene $\mathbf{5}$ (1.0 equiv, $0.30 \mathrm{mmol}$ ) were added and the mixture was stirred at $50{ }^{\circ} \mathrm{C}$ (oil bath) for $3 \mathrm{~d}$ (for experimental details, see Table 5). After cooling to room temperature, brine $(15 \mathrm{~mL})$ was added to stop the reaction. The aqueous phase was extracted with dichloromethane $(3 \times 20 \mathrm{~mL})$. The combined organic layers were dried with anhydrous magnesium sulfate, filtered and the solvent was removed under reduced pressure to give the crude product 4 .

$\begin{aligned} & \text { Table } \mathbf{5} \\
& \text { dithienothiazine copolymers } \mathbf{4}\end{aligned}$
\begin{tabular}{lll} 
Entry & Diiodo(hetero)arene $\mathbf{5}$ & $\begin{array}{l}\text { Dithienothiazine } \\
\text { copolymer } \mathbf{4} \text { (yield) }\end{array}$ \\
\hline 1 & $99 \mathrm{mg}(0.30 \mathrm{mmol})$ of $\mathbf{5 a}$ & $220 \mathrm{mg}(99 \%)$ of $\mathbf{4 a}$ \\
2 & $99 \mathrm{mg}(0.30 \mathrm{mmol})$ of $\mathbf{5 b}$ & $225 \mathrm{mg} \mathrm{(99 \% )} \mathrm{of} \mathbf{4 b}$ \\
3 & $107 \mathrm{mg}(0.30 \mathrm{mmol})$ of $\mathbf{5 c}$ & $212 \mathrm{mg} \mathrm{(92 \% )} \mathrm{of} \mathbf{4 c}$ \\
4 & $99 \mathrm{mg}(0.30 \mathrm{mmol})$ of $\mathbf{5 d}$ & $229 \mathrm{mg} \mathrm{(100 \% )} \mathrm{of} \mathbf{4 e}$ \\
5 & $99 \mathrm{mg}(0.30 \mathrm{mmol})$ of $\mathbf{5 e}$ & $228 \mathrm{mg} \mathrm{(100 \% )} \mathrm{of} \mathbf{4 f}$ \\
\hline
\end{tabular}

Poly[4-(4-((2-decyltetradecyl)oxy)phenyl)-4Hdithieno[2,3-b:3',2'-e][1,4]thiazin-2,6-yl-alt-1, 4-phenylene] (4a)

The crude product obtained according to GP1 was suspended in acetone $(25 \mathrm{~mL})$, placed in the ultrasound bath for $25 \mathrm{~min}$ and after filtration the residue was dried under reduced pressure to give polymer $\mathbf{4 a}(272 \mathrm{mg}, 92 \%)$ as a dark brown solid, Mp $174-180^{\circ} \mathrm{C}$.

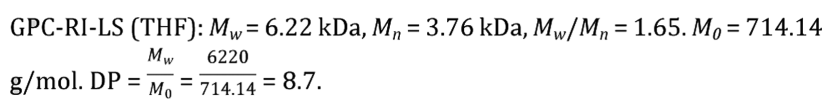

The crude product obtained according to GP2 was suspended in acetone $(20 \mathrm{~mL})$, placed in the ultrasound bath for $15 \mathrm{~min}$ and after filtration the residue was dried under reduced pressure to give polymer $\mathbf{4 a}(220 \mathrm{mg}$, 99\%) as a dark brown solid, Mp $174-180{ }^{\circ} \mathrm{C}$.

GPC-RI-LS (THF): $M_{w}=8.9 \mathrm{kDa}, M_{n}=5.9 \mathrm{kDa}, M_{w} / M_{n}=1.51 . M_{0}=714.14$ $\mathrm{g} / \mathrm{mol} . \mathrm{DP}=\frac{M_{w}}{M_{0}}=\frac{8900}{714.14}=12.5$.

IR $\tilde{\nu}\left[\mathrm{cm}^{-1}\right]$ ]: $2920(\mathrm{~m}), 2850(\mathrm{w}), 1504$ (s), $1493(\mathrm{~m}), 1483$ (w), $1463(\mathrm{w}), 1456(\mathrm{w}), 1427(\mathrm{w}), 1409(\mathrm{w}), 1377(\mathrm{w}), 1276$ (w), $1240(\mathrm{~m}), 1165(\mathrm{w}), 1103(\mathrm{w}), 1062(\mathrm{w}), 1045(\mathrm{w}), 1024$ (w), $997(w), 977(w), 947(w), 839(w), 808(m), 765(w)$, $721(w), 692(w), 681(w), 665(w)$.

${ }^{1} \mathrm{H}$ NMR $\left(\right.$ THF- $\left.d_{8}, 600 \mathrm{MHz}\right): \delta=6.03-7.80(\mathrm{~m}, 10 \mathrm{H})$, 3.70-3.99 (m, $2 \mathrm{H}), 1.81-184(\mathrm{~m}, 1 \mathrm{H}), 1.29-1.55(\mathrm{~m}, 40 \mathrm{H})$, $0.78-0.97(\mathrm{~m}, 6 \mathrm{H})$.

${ }^{13} \mathrm{C}$ NMR (THF- $\left.d_{8}, 150 \mathrm{MHz}\right): \delta=160.1$ ( $\left.\mathrm{C}_{\text {quat }}\right), 143.4$ $\left(C_{\text {quat }}\right), 139.0\left(C_{\text {quat }}\right), 133.3\left(C_{\text {quat }}\right), 133.2\left(C_{\text {quat }}\right), 131.32(\mathrm{CH})$, $131.28(\mathrm{CH}), 127.4(\mathrm{CH}), 126.1(\mathrm{CH}), 116.92\left(\mathrm{C}_{\text {quat }}\right), 116.89$ $\left(\mathrm{C}_{\text {quat }}\right), 116.1(\mathrm{CH}), 101.6\left(\mathrm{C}_{\text {quat }}\right), 72.0\left(\mathrm{CH}_{2}\right), 39.4(\mathrm{CH}), 33.1$ $\left(\mathrm{CH}_{2}\right), 32.6\left(\mathrm{CH}_{2}\right), 31.2\left(\mathrm{CH}_{2}\right), 30.85\left(\mathrm{CH}_{2}\right), 30.81\left(\mathrm{CH}_{2}\right), 30.5$ $\left(\mathrm{CH}_{2}\right), 28.1\left(\mathrm{CH}_{2}\right), 23.8\left(\mathrm{CH}_{2}\right), 14.7\left(\mathrm{CH}_{3}\right)$.

MS (MALDI): $\left.m / z=1043.219([I-p-p h-(D T T-p h)-I)]^{+}\right)$, $1554.675\left(\left[(\mathrm{DTT}-p-\mathrm{ph})_{2}-\mathrm{I}\right]^{+}\right), 1756.602([\mathrm{I}-p-\mathrm{ph}-[(\mathrm{DTT}-p-$ $\left.\left.\mathrm{ph})_{2}-\mathrm{I}\right]^{+}\right), 2269.053\left(\left[(\mathrm{DTT}-\mathrm{p}-\mathrm{ph})_{3}-\mathrm{I}\right]^{+}\right), 2471.245$ ([I-(p-phDTT $)_{3}-p-$ ph-I $]^{+}$.

\section{Poly[4-(4-((2-decyltetradecyl)oxy)phenyl)-4H- dithieno[2,3-b:3',2'-e][1,4]thiazin-2,6-yl-alt-1, 3-phenylene] (4b)}

The crude product obtained according to GP2 was suspended in acetone $(15 \mathrm{~mL})$, placed in the ultrasound bath for $15 \mathrm{~min}$ and after filtration the residue was dried under reduced pressure to give polymer $\mathbf{4 b}(225 \mathrm{mg}, 99 \%)$ as a dark red resin, $\mathrm{Mp}>300^{\circ} \mathrm{C}$. 
GPC-RI-LS (THF): $M_{w}=6.14 \mathrm{kDa}, M_{n}=3.74 \mathrm{kDa}, M_{w} / M_{n}=1.64 . M_{0}$ ) $=$ $714.14 \mathrm{~g} / \mathrm{mol} . \mathrm{DP}=\frac{M_{w}}{M_{0}}=\frac{6140}{714.14}=8.6$.

IR $\tilde{\nu}\left[\mathrm{cm}^{-1}\right]$ : $2958(\mathrm{w}), 2920(\mathrm{~s}), 2870(\mathrm{w}), 1597(\mathrm{w}), 1585$ (w), $1568(\mathrm{w}), 1533(\mathrm{w}), 1506(\mathrm{~m}), 1464(\mathrm{~m}), 1456(\mathrm{w}), 1435$ (w), $1417(\mathrm{w}), 1377(\mathrm{w}), 1363(\mathrm{w}), 1338(\mathrm{w}), 1257(\mathrm{~m}), 1242$ (m), $1184(\mathrm{w}), 1165$ (w), 1093 (m), 1016 (s), 937 (w), 864 (w), $837(\mathrm{w}), 817(\mathrm{~m}), 789(\mathrm{~s}), 742(\mathrm{w}), 719(\mathrm{w}), 690(\mathrm{~m})$, $659(\mathrm{w})$.

${ }^{1} \mathrm{H}$ NMR (THF- $\left.d_{8}, 600 \mathrm{MHz}\right): \delta=6.02-7.74(\mathrm{~m}, 10 \mathrm{H})$, 3.70-4.00 (br, 2 H), 1.82-1.85 (br, $1 \mathrm{H}), 1.28-1.56$ (m, $40 \mathrm{H})$, 0.80-0.89 (m, $6 \mathrm{H})$.

${ }^{13} \mathrm{C}$ NMR (THF- $\left.d_{8}, 150 \mathrm{MHz}\right): \delta=160.1$ (C quat), 154.3 ( $\left.\mathrm{C}_{\text {quat }}\right), 145.5\left(\mathrm{C}_{\text {quat }}\right), 137.0\left(\mathrm{C}_{\text {quat }}\right), 134.3\left(\mathrm{C}_{\text {quat }}\right), 133.3(\mathrm{CH})$, $133.1(\mathrm{CH}), 133.0(\mathrm{CH}), 132.6\left(\mathrm{C}_{\text {quat }}\right), 132.3\left(\mathrm{C}_{\text {quat }}\right), 131.2$ $(\mathrm{CH}), 129.34(\mathrm{CH}), 129.29(\mathrm{CH}), 117.0(\mathrm{CH}), 116.9(\mathrm{CH}), 115.8$ (CH), 101.1 ( $\left.\mathrm{C}_{\text {quat }}\right), 72.0\left(\mathrm{CH}_{2}\right), 39.4(\mathrm{CH}), 33.1\left(\mathrm{CH}_{2}\right), 32.6$ $\left(\mathrm{CH}_{2}\right), 31.2\left(\mathrm{CH}_{2}\right), 30.9\left(\mathrm{CH}_{2}\right), 30.8\left(\mathrm{CH}_{2}\right), 30.5\left(\mathrm{CH}_{2}\right), 28.1$ $\left(\mathrm{CH}_{2}\right), 26.6\left(\mathrm{CH}_{2}\right), 23.8\left(\mathrm{CH}_{2}\right), 14.7\left(\mathrm{CH}_{3}\right)$.

MS (MALDI): $\quad m / z=841.248 \quad$ ([(DTT- $\left.m-\mathrm{ph})-\mathrm{I}]^{+}\right)$, 1043.279 ([I-m-ph-(DTT-m-ph)-I $\left.]^{+}\right), 1555.746$ ([(DTT-m$\left.\left.\mathrm{ph})_{2}-\mathrm{I}\right]^{+}\right), 1757.701$ ([I-m-ph-(DTT-m-ph) $\left.\left.)_{2}-\mathrm{I}\right]^{+}\right), 2269.150$ $\left(\left[(\mathrm{DTT}-m-\mathrm{ph})_{3}-\mathrm{I}\right]^{+}\right)$.

\section{Poly[4-(4-((2-decyltetradecyl)oxy)phenyl)-4H- dithieno[2,3-b:3',2'-e][1,4]thiazin-2,6-yl-alt-2, 5-dimethyl-1,4-phenylene] (4c)}

The crude product obtained according to GP2 was suspended in acetone $(15 \mathrm{~mL})$, placed in the ultrasound bath for $15 \mathrm{~min}$ and after decantation of the supernatant the residue was dried under reduced pressure to give polymer 4c (212 $\mathrm{mg}, 92 \%)$ as a dark red resin.

GPC-RI-LS (THF): $M_{w}=7.27 \mathrm{kDa}, M_{n}=4.24 \mathrm{kDa}, M_{w} / M_{n}=1.71 . M_{0}=742.20$ $\mathrm{g} / \mathrm{mol} . \mathrm{DP}=\frac{M_{w}}{M_{0}}=\frac{7270}{742.2}=9.8$.

IR $\tilde{\nu}\left[\mathrm{cm}^{-1}\right]$ : $2987(\mathrm{w}) 2920(\mathrm{~s}), 2872(\mathrm{~m}), 1701(\mathrm{w}), 1558$ (w), 1504 (s), 1456 (w), 1435 (w), 1379 (w), 1354 (w), 1296 (w), $1278(\mathrm{w}), 1240(\mathrm{~m}), 1166(\mathrm{w}), 1072(\mathrm{w}), 1037(\mathrm{w}), 997$ (w), $974(\mathrm{w}), 889(\mathrm{w}), 742(\mathrm{w}), 721(\mathrm{w}), 692(\mathrm{w}), 620(\mathrm{~m})$.

${ }^{1} \mathrm{H}$ NMR $\left(\right.$ THF- $\left.d_{8}, 600 \mathrm{MHz}\right): \delta=6.01-7.75(\mathrm{~m}, 8 \mathrm{H})$, 3.75-3.95 (br, 2 H), 2.08-2.57 (m, $6 \mathrm{H}), 1.75-1.83$ (br, $1 \mathrm{H})$, 1.28-1.52 (m, $40 \mathrm{H}), 0.79-0.90(\mathrm{~m}, 6 \mathrm{H})$.

${ }^{13} \mathrm{C}$ NMR (THF- $\left.d_{8}, 150 \mathrm{MHz}\right): \delta=145.4$ (C quat), 141.8 ( $\left.C_{\text {quat }}\right), 134.2\left(\mathrm{C}_{\text {quat }}\right), 133.3\left(\mathrm{C}_{\text {quat }}\right), 133.2\left(\mathrm{C}_{\text {quat }}\right), 132.8(\mathrm{CH})$, $131.3(\mathrm{CH}), 131.01(\mathrm{CH}), 130.03(\mathrm{CH}), 129.34\left(\mathrm{C}_{\text {quat }}\right), 129.26$ $\left(\mathrm{C}_{\text {quat }}\right), 119.9(\mathrm{CH}), 116.8\left(\mathrm{C}_{\text {quat }}\right), 115.8(\mathrm{CH}), 101.1\left(\mathrm{C}_{\text {quat }}\right)$, $71.8\left(\mathrm{CH}_{2}\right), 47.9\left(\mathrm{C}_{\text {quat }}\right), 39.3(\mathrm{CH}), 33.0\left(\mathrm{CH}_{2}\right), 32.55\left(\mathrm{CH}_{2}\right)$, $32.50\left(\mathrm{CH}_{2}\right), 31.2\left(\mathrm{CH}_{2}\right), 30.82\left(\mathrm{CH}_{2}\right), 30.78\left(\mathrm{CH}_{2}\right), 30.5\left(\mathrm{CH}_{2}\right)$, $28.0\left(\mathrm{CH}_{2}\right), 23.7\left(\mathrm{CH}_{2}\right), 14.7\left(\mathrm{CH}_{3}\right)$.

MS (MALDI): $m / z=869.280 \quad\left([(D T T-2,6-p-x y l)-I]^{+}\right)$, $1099.232\left([\mathrm{I}-2,6-p-\mathrm{xyl}-(\mathrm{DTT}-2,6-p-\mathrm{xyl})-\mathrm{I}]^{+}\right), \quad 1610.670$
$\left(\left[(\mathrm{DTT}-2,6-p-\mathrm{xyl})_{2}-\mathrm{I}\right]^{+}\right), 1840.620([\mathrm{I}-2,6-p-\mathrm{xyl}-(\mathrm{DTT}-2,6-p-$ $\left.\left.\mathrm{xyl})_{2}-\mathrm{I}\right]^{+}\right), 2353.052\left(\left[(\mathrm{DTT}-2,6-p-\mathrm{xyl})_{3}-\mathrm{I}\right]^{+}\right), 2582.997([\mathrm{I}-$ 2,6-p-xyl-(DTT-2,6-p-xyl $\left.\left.)_{3}-\mathrm{I}\right]^{+}\right)$.

\section{Poly[4-(4-((2-decyltetradecyl)oxy)phenyl)-4H- dithieno[2,3-b:3',2'-e][1,4]thiazin-2,6-yl-alt-4, 4'-biphenylene] (4d)}

The crude product obtained according to GP1 was suspended in acetone $(25 \mathrm{~mL})$, placed in the ultrasound bath for $25 \mathrm{~min}$ and after filtration the residue was dried under reduced pressure to give polymer $4 \mathbf{d}$ (204 $\mathrm{mg}, 63 \%$ ) as a sparingly soluble black solid, $\mathrm{Mp}>300{ }^{\circ} \mathrm{C}$.

GPC-RI-LS (THF): $M_{w}=16.5 \mathrm{kDa}, M_{n}=10.4 \mathrm{kDa}, M_{w} / M_{n}=1.59 . M_{0}=790.24$ $\mathrm{g} / \mathrm{mol} . \mathrm{DP}=\frac{M_{w}}{M_{0}}=\frac{16500}{790.24}=20.9$.

IR $\tilde{\nu}\left[\mathrm{cm}^{-1}\right]: 2920(\mathrm{~s}), 2850(\mathrm{~m}), 1504(\mathrm{~s}), 1490(\mathrm{~s}), 1465(\mathrm{~m})$, $1435(\mathrm{~m}), 1411$ (w), $1400(\mathrm{w}), 1377(\mathrm{w}), 1298(\mathrm{w}), 1274(\mathrm{w})$, 1240 (s), $1165(w), 1105(w), 1029(w), 1001(w), 839(w)$, $808(\mathrm{~s}), 763(\mathrm{w}), 719(\mathrm{w}), 694(\mathrm{w})$.

MS (MALDI): $m / z=839.445$ ([(DTT-4,4'-biph)-B(OH) $\left.]^{+}\right)$, 1428.834 ([DTT-4,4'-biph-DTT $\left.]^{+}\right), 2219.263$ ([(DTT-4,4'biph $)_{2}-$ DTT $\left.]^{+}\right), 3008.729\left(\left[(\text { DTT-4,4'-biph })_{3}-\text { DTT }\right]^{+}\right)$.

\section{Poly[4-(4-((2-decyltetradecyl)oxy)phenyl)-4H- dithieno[2,3-b:3',2'-e][1,4]thiazin-2,6-yl-alt-2,5- pyridyl] (4e)}

The crude product obtained according to GP2 was suspended in acetone $(20 \mathrm{~mL})$, placed in the ultrasound bath for $15 \mathrm{~min}$ and after filtration the residue was dried under reduced pressure to give polymer $4 \mathbf{e}(229 \mathrm{mg}, 100 \%)$ as a black solid, $\mathrm{Mp}>300{ }^{\circ} \mathrm{C}$ (dec.).

GPC-RI-LS (THF): $M_{w}=14.1 \mathrm{kDa}, M_{n}=8.41 \mathrm{kDa}, M_{w} / M_{n}=1.68 . M_{0}=715.12$ $\mathrm{g} / \mathrm{mol} . \mathrm{DP}=\frac{M_{w}}{M_{0}}=\frac{14100}{715.13}=19.7$.

IR $\tilde{\nu}\left[\mathrm{cm}^{-1}\right]: 2920(\mathrm{~s}), 2850(\mathrm{~m}), 1573(\mathrm{w}), 1556(\mathrm{w}), 1531$ (w), $1504(\mathrm{~s}), 1471(\mathrm{~s}), 1417(\mathrm{~m}), 1377(\mathrm{w}), 1365(\mathrm{w}), 1292$ (w), $1276(\mathrm{w}), 1240(\mathrm{~s}), 1186(\mathrm{w}), 1166(\mathrm{w}), 1134(\mathrm{w}), 1101$ (w), $1076(w), 1047(w), 1022(w), 997(w), 975(w), 964(w)$, 945 (w), 918 (w), 893 (w), $839(w), 813(w), 765(w), 742$ (w), $721(\mathrm{w}), 692(\mathrm{w}), 667(\mathrm{w}), 615(\mathrm{w})$.

${ }^{1} \mathrm{H}$ NMR $\left(\right.$ THF- $\left.d_{8}, 600 \mathrm{MHz}\right): \delta=6.01-8.59(\mathrm{~m}, 9 \mathrm{H})$, 3.74-3.93 (br, $2 \mathrm{H}), 1.83$ (br, $1 \mathrm{H}), 1.28-1.54(\mathrm{~m}, 40 \mathrm{H})$, 0.80-0.90 (m, $6 \mathrm{H})$.

${ }^{13} \mathrm{C}$ NMR (THF- $\left.d_{8}, 150 \mathrm{MHz}\right): \delta=160.8\left(\mathrm{C}_{\text {quat }}\right), 145.6$ $\left(\mathrm{C}_{\text {quat }}\right), 134.0$ ( $\left.\mathrm{C}_{\text {quat }}\right), 133.6\left(\mathrm{C}_{\text {quat }}\right), 132.5\left(\mathrm{C}_{\text {quat }}\right), 131.43(\mathrm{CH})$, 131.37 (CH), 129.4 ( $\left.\mathrm{C}_{\text {quat }}\right), 117.0(\mathrm{CH}), 116.97(\mathrm{CH}), 116.94(\mathrm{CH})$, $101.1\left(\mathrm{C}_{\text {quat }}\right), 71.8\left(\mathrm{CH}_{2}\right), 39.4(\mathrm{CH}), 33.1\left(\mathrm{CH}_{2}\right), 32.6\left(\mathrm{CH}_{2}\right), 31.2$ $\left(\mathrm{CH}_{2}\right), 30.8\left(\mathrm{CH}_{2}\right), 30.5\left(\mathrm{CH}_{2}\right), 28.0\left(\mathrm{CH}_{2}\right), 23.8\left(\mathrm{CH}_{2}\right), 14.7\left(\mathrm{CH}_{3}\right)$. 
MS (MALDI): $\quad m / z=1556.659 \quad\left(\left[(D T T-2,5-p y)_{2}-I\right]^{+}\right)$, 1759.579 ([I-2,5-py-(DTT-2,5-py) $\left.\left.)_{2}-\right]^{+}\right), 2272.027$ ([(DTT2,5-py $\left.\left.)_{3}-\mathrm{I}\right]^{+}\right), \quad 2474.958 \quad\left(\left[\mathrm{I}-2,5-\mathrm{py}-(\mathrm{DTT}-2,5-\mathrm{py})_{3}-\mathrm{I}\right]^{+}\right)$, $3189.435\left(\left[\mathrm{I}-2,5-\text { py-(DTT-2,5-py) }{ }_{4}-\mathrm{I}\right]^{+}\right)$.

\section{Poly[4-(4-((2-decyltetradecyl)oxy)phenyl)-4H- dithieno[2,3-b:3',2'-e][1,4] thiazin-2,6-yl-alt-2, 6-pyridyl] (4f)}

The crude product obtained according to GP2 was suspended in acetone $(20 \mathrm{~mL})$, placed in the ultrasound bath for $15 \mathrm{~min}$ and after filtration the residue was dried under reduced pressure to give polymer $\mathbf{4 f}(228 \mathrm{mg}, 100 \%)$ as a dark brown solid, Mp $95-98{ }^{\circ} \mathrm{C}$.

GPC-RI-LS (THF): $M_{w}=6.02 \mathrm{kDa}, M_{n}=4.41 \mathrm{kDa}, M_{w} / M_{n}=1.35 . M_{0}=715.13$ $\mathrm{g} / \mathrm{mol} . \mathrm{DP}=\frac{M_{w}}{M_{0}}=\frac{6020}{715.13}=8.4$.

IR $\tilde{\nu}\left[\mathrm{cm}^{-1}\right.$ ]: 2920 (s), 2850 (m), $2160(\mathrm{w}), 1575(\mathrm{w}), 1558$ (m), $1541(\mathrm{w}), 1504(\mathrm{~m}), 1442(\mathrm{~s}), 1419(\mathrm{~m}), 1394(\mathrm{w}), 1377$ (w), $1367(\mathrm{w}), 1298(\mathrm{w}), 1242(\mathrm{~m}), 1186(\mathrm{w}), 1159(\mathrm{w}), 1109$ (w), $1078(w), 1045(w), 1026(w), 1004(w), 997(w), 979$ (w), $950(w), 894(w), 839(w), 825(w), 792(m), 783(w)$, $763(\mathrm{w}), 723(\mathrm{w}), 704(\mathrm{w}), 692(\mathrm{w}), 621(\mathrm{~m})$.

${ }^{1} \mathrm{H}$ NMR $\left(\right.$ THF- $\left.d_{8}, 600 \mathrm{MHz}\right): \delta=6.02-7.75(\mathrm{~m}, 9 \mathrm{H})$, 3.75-3.95 (br, $2 \mathrm{H}), 1.82-1.85$ (br, 1H), 1.28-1.57 (m, $40 \mathrm{H})$, 0.83-0.89 (m, $6 \mathrm{H})$.

${ }^{13} \mathrm{C}$ NMR $\left(\right.$ THF- $\left.d_{8}, 150 \mathrm{MHz}\right): \delta=163.0\left(\mathrm{C}_{\text {quat }}\right), 151.8$ $\left(\mathrm{C}_{\text {quat }}\right), 142.6\left(\mathrm{C}_{\text {quat }}\right), 133.7\left(\mathrm{C}_{\text {quat }}\right), 133.32\left(\mathrm{C}_{\text {quat }}\right), 133.28$ $\left(\mathrm{C}_{\text {quat }}\right), 131.4(\mathrm{CH}), 129.6\left(\mathrm{C}_{\text {quat }}\right), 129.4\left(\mathrm{C}_{\text {quat }}\right), 129.3$ ( $\left.\mathrm{C}_{\text {quat }}\right)$, $126.1\left(\mathrm{C}_{\text {quat }}\right), 117.7(\mathrm{CH}), 117.0(\mathrm{CH}), 116.8(\mathrm{CH}), 104.4$ ( $\left.\mathrm{C}_{\text {quat }}\right), 101.1\left(\mathrm{C}_{\text {quat }}\right), 72.0\left(\mathrm{CH}_{2}\right), 39.4(\mathrm{CH}), 33.0\left(\mathrm{CH}_{2}\right), 32.6$ $\left(\mathrm{CH}_{2}\right), 31.2\left(\mathrm{CH}_{2}\right), 30.82\left(\mathrm{CH}_{2}\right), 30.79\left(\mathrm{CH}_{2}\right), 30.5\left(\mathrm{CH}_{2}\right), 28.1$ $\left(\mathrm{CH}_{2}\right), 23.7\left(\mathrm{CH}_{2}\right), 14.6\left(\mathrm{CH}_{3}\right)$.

MS (MALDI): $m / z=1045.221$ ([I-2,6-py-(DTT-2,6-py)I $\left.]^{+}\right), 1557.680\left(\left[(\text { DTT-2,6-py })_{2}-\mathrm{I}\right]^{+}\right), 1759.602$ ([I-2,6-py$\left.\left.(\text { DTT-2,6-py })_{2}-\mathrm{I}\right]^{+}\right), 2272.054\left(\left[(\text { DTT-2,6-py })_{3}-\mathrm{I}\right]^{+}\right), 2474.987$ ([I-2,6-py-(DTT-2,6-py) $\left.\left.{ }_{3}-\mathrm{I}\right]^{+}\right), \quad 2986.498$ ([(DTT-2,6-py $)_{4^{-}}$ I $\left.\left.]^{+}\right), 3189.435\left([\mathrm{I}-2,6-\text { py-(DTT-2,6-py })_{4}-\mathrm{I}\right]^{+}\right)$.

\section{Poly[4-(4-((2-decyltetradecyl)oxy)phenyl)-4H- dithieno[2,3-b:3',2'-e][1,4]thiazin-2,6-yl-alt-4, 7-benzo[c][1,2,5]thiadiazolyl] $(4 \mathrm{~g})$}

The crude product obtained according to GP1 was suspended in acetone $(20 \mathrm{~mL})$, placed in the ultrasound bath for $15 \mathrm{~min}$. Then the solid was suspended twice in acetone $(2 \times 10 \mathrm{~mL})$ and the supernatant was decanted. After filtration the residue was dried under reduced pressure to give polymer $\mathbf{4 g}$ (290 $\mathrm{mg}, 85 \%)$ as a sparingly soluble dark green solid, $\mathrm{Mp}>300{ }^{\circ} \mathrm{C}$ (dec.).
GPC-RI-LS (THF): $M_{w}=2.95 \mathrm{kDa}, M_{n}=2.46 \mathrm{kDa}, M_{w} / M_{n}=1.20 . M_{0}=772.20$ $\mathrm{g} / \mathrm{mol} . \mathrm{DP}=\frac{M_{w}}{M_{0}}=\frac{2950}{772.20}=3.8$.

IR $\tilde{\nu}\left[\mathrm{cm}^{-1}\right]$ : $2920(\mathrm{~m}), 2850(\mathrm{~m}), 1506(\mathrm{~m}), 1483(\mathrm{~s}), 1467$ (m), 1426 (s), $1411(\mathrm{~s}), 1375(\mathrm{~m}), 1352(\mathrm{w}), 1338(\mathrm{w}), 1298$ (w), 1240 (m), $1184(\mathrm{w}), 1165(\mathrm{w}), 1103(\mathrm{w}), 1049(\mathrm{w}), 1022$ (w), $1008(\mathrm{w}), 864(\mathrm{w}), 837(\mathrm{~m}), 819(\mathrm{~m}), 788(\mathrm{w}), 765(\mathrm{w})$, $719(\mathrm{w}), 638(\mathrm{w})$.

MS (MALDI): $\quad m / z=1410.746 \quad\left([D T T-(B T D-D T T)]^{+}\right)$, $\left.\left.2183.107\left([\text { DTT-(BTD-DTT })_{2}\right]^{+}\right), 2955.468\left([\text { DTT-(BTD-DTT) })_{3}\right]^{+}\right)$.

\section{Poly[4-(4-((2-decyltetradecyl)oxy)phenyl)-4H- dithieno[2,3-b:3',2'-e][1,4] thiazin-2,6-yl-alt-10- hexyl-10H-phenothiazin-3,7-yl] (4h)}

The crude product obtained according to GP1 was suspended in acetone $(20 \mathrm{~mL})$, placed in the ultrasound bath for $30 \mathrm{~min}$ and after filtration the residue was dried under reduced pressure to give polymer $\mathbf{4 h}(374 \mathrm{mg}, 99 \%)$ as a dark brown resin, Mp $124-128{ }^{\circ} \mathrm{C}$.

GPC-RI-LS (THF): $M_{w}=13.7 \mathrm{kDa}, M_{n}=10.1 \mathrm{kDa}, M_{w} / M_{n}=1.36 . M_{0}=919.46$ $\mathrm{g} / \mathrm{mol} . \mathrm{DP}=\frac{M_{w}}{M_{0}}=\frac{13700}{919.46}=14.9$.

$\operatorname{IR} \tilde{\nu}\left[\mathrm{cm}^{-1}\right]: 2953(\mathrm{w}), 2920(\mathrm{~m}), 2850(\mathrm{w}), 1620(\mathrm{w}), 1575(\mathrm{w})$, $1571(\mathrm{w}), 1550(\mathrm{w}), 1508(\mathrm{~m}), 1469(\mathrm{~s}), 1463(\mathrm{~s}), 1460(\mathrm{~s})$, $1452(\mathrm{~m}), 1438(\mathrm{w}), 1400(\mathrm{w}), 1354(\mathrm{w}), 1332(\mathrm{w}), 1296(\mathrm{w})$, $1244(\mathrm{~s}), 1190(\mathrm{w}), 1165(\mathrm{w}), 1141(\mathrm{w}), 1103(\mathrm{w}), 1020(\mathrm{w})$, $869(\mathrm{w}), 839(\mathrm{w}), 802(\mathrm{~m}), 765(\mathrm{w}), 746(\mathrm{w}), 721(\mathrm{w}), 692(\mathrm{w})$.

${ }^{1} \mathrm{H} \mathrm{NMR}\left(\mathrm{THF}-\mathrm{d}_{8}, 600 \mathrm{MHz}\right): \delta=6.00-7.75(\mathrm{~m}, 12 \mathrm{H})$, 3.78-3.98 (m, $4 \mathrm{H}), 1.83-1.87$ (br, $1 \mathrm{H}), 1.29-1.62(\mathrm{~m}, 46 \mathrm{H})$, $0.78-1.00(\mathrm{~m}, 9 \mathrm{H})$.

${ }^{13} \mathrm{C}$ NMR $\left(\right.$ THF- $\left.d_{8}, 150 \mathrm{MHz}\right): \delta=160.1$ ( $\left.\mathrm{C}_{\text {quat }}\right), 156.5$ $\left(\mathrm{C}_{\text {quat }}\right), 145.7\left(\mathrm{C}_{\text {quat }}\right), 145.3\left(\mathrm{C}_{\text {quat }}\right), 141.3\left(\mathrm{C}_{\text {quat }}\right), 137.1$ $\left(\mathrm{C}_{\text {quat }}\right), 133.0\left(\mathrm{C}_{\text {quat }}\right), 132.9\left(\mathrm{C}_{\text {quat }}\right), 131.2(\mathrm{CH}), 129.4(\mathrm{CH})$, 129.3 (CH), $129.2(\mathrm{CH}), 125.8\left(\mathrm{C}_{\text {quat }}\right), 125.0(\mathrm{CH}), 124.2(\mathrm{CH})$, $116.9(\mathrm{CH}), 116.6(\mathrm{CH}), 116.4(\mathrm{CH}), 115.5(\mathrm{CH}), 101.4\left(\mathrm{C}_{\text {quat }}\right)$, 84.5 ( $\left.\mathrm{C}_{\text {quat }}\right), 72.0(\mathrm{CH}), 48.2\left(\mathrm{CH}_{2}\right), 39.4(\mathrm{CH}), 32.6\left(\mathrm{CH}_{2}\right), 32.6$ $\left(\mathrm{CH}_{2}\right), 31.2\left(\mathrm{CH}_{2}\right), 30.9\left(\mathrm{CH}_{3}\right), 30.8\left(\mathrm{CH}_{2}\right), 30.5\left(\mathrm{CH}_{2}\right), 28.1$ $\left(\mathrm{CH}_{2}\right), 27.7\left(\mathrm{CH}_{2}\right), 27.5\left(\mathrm{CH}_{2}\right), 23.8\left(\mathrm{CH}_{2}\right), 23.7\left(\mathrm{CH}_{2}\right), 20.8$ $\left(\mathrm{CH}_{2}\right), 14.7\left(\mathrm{CH}_{3}\right), 14.5\left(\mathrm{CH}_{3}\right), 14.3\left(\mathrm{CH}_{3}\right)$.

MS (MALDI): $m / z=1327.681$ ([pinB-PT-(DTT-PT)] ${ }^{+}$), 1453.764 ([pinB-PT-(DTT-PT)-Bpin] $\left.]^{+}\right), 2247.143$ ([pinB-PT$\left.\left.\left.(\text { DTT-PT })_{2}\right]^{+}\right), \quad 2372.227 \quad\left([\text { pinB-PT-(DTT-PT })_{2}-\text { Bpin }\right]^{+}\right)$, 3165.621 ([pinB-PT-(DTT-PT) $\left.\left.]_{3}^{+}\right]^{+}\right), 3291.700$ ([pinB-PT$(\text { DTT-PT })_{3}$-Bpin $\left.\left.]^{+}\right), \quad 4087.500 \quad\left([\text { pinB-PT-(DTT-PT })_{4}\right]^{+}\right)$, 4213.300 ([pinB-PT-(DTT-PT) $)_{4}$-Bpin $]^{+}$).

\section{Funding Information}

The authors gratefully acknowledge the Ernst Jäger Foundation (scholarship for Jennifer Nau) and the Deutsche 
Forschungsgemeinschaft (Mu 1088/9-1) for the financial support.

\section{Acknowledgment}

The authors are very grateful to Ms. Stephanie Scheelen (group of Prof. L. Hartmann, HHU Düsseldorf) for gel permeation chromatography measurements and Dr. Alexa Schmitz (group of Prof. C. Janiak, HHU Düsseldorf) for thermogravimetric analyses of compounds 4 .

\section{Supporting Information}

Supporting Information for this article is available online at https://doi.org/10.1055/a-1528-6301.

\section{References}

(1) (a) MacDiarmid, A. G. Angew. Chem. Int. Ed. 2001, 40, 2581. (b) Kiess, H. G. Conjugated conducting polymers. Vol. 102,,Springer: Heidelberg, 1992.

(2) Rasmussen, S. C. ChemPlusChem 2020, 85, 1412.

(3) (a) Fratini,S.; Nikolka, M.; Salleo, A.; Schweicher, G.; Sirringhaus, H. Nat. Mater. 2020, 19, 491. (b) Wang, C.; Zhang, X.; Hu, W.Chem. Soc. Rev. 2020, 49, 653. (c) Bronstein, H.; Nielsen, C. B.; Schroeder, B. C.; McCulloch, I.Nat. Rev. Chem. 2020, 4, 66. (d) Bhosale, M. E.; Chae, S.; Kim, J. M.; Choi, J.-Y.J. Mater. Chem. A 2018, 6, 19885. (e) Bujak, P.; Kulszewicz-Bajer, I.; Zagorska, M.; Maurel, V.; Wielgus, I.; Pron, A. Chem. Soc. Rev. 2013, 42, 8895. (f) Dong, H.; Zhu, H.; Meng, Q.; Gong, X.; Hu, W. Chem. Soc. Rev. 2012, 41, 1754.

(4) (a) Jayakumar, J.; Chou, H.-H. ChemCatChem 2020, 12, 689. (b) Dai, C.; Liu, B. Energy Environ. Sci. 2020, 13, 24.

(5) (a) Li, J.; Pu, K. Chem. Soc. Rev. 2019, 48, 38. (b) Nezakati, T.; Seifalian, A.; Tan, A.; Seifalian, A. M. Chem. Rev. 2018, 118, 6766.

(6) (a) Mazzio, K. A.; Luscombe, C. K. Chem. Soc. Rev. 2015, 44, 78. (b) Facchetti, A. Chem. Mater. 2011, 23, 733. (c) Cheng, Y.-J.; Yang, S.H.; Hsu, C.-S. Chem. Rev. 2009, 109, 5868.
(7) Ying, L.; Huang, F.; Bazan, G. C. Nat. Commun. 2017, 8, 14047.

(8) Wang, J.; Liu, K.; Ma, L.; Zhan, X. Chem. Rev. 2016, 116, 14675.

(9) Cinar, M. E.; Ozturk, T. Chem. Rev. 2015, 115, 3036.

(10) Aitken, R. A.; Aitken, K. M. 1,4-Thiazines and their Benzo Derivatives. In: Comprehensive Heterocyclic Chemistry III. Katritzky, A. R.; Ramsden, A. C.; Scriven, E. F. .. V.; Taylor, R. J. K.; Elsevier: Amsterdam, 2008, 607.

(11) Perețeanu, I. S.; Müller, T. J. J. Org. Biomol. Chem. 2013, 11, 5127.

(12) (a) Park, Y.; Kim, B.; Lee, C.; Hyun, A.; Jang, S.; Lee, J.-H.; Gal, Y.-S.; Kim, T. H.; Kim, K.-S.; Park, J.J. Phys. Chem. C 2011, 115, 4843. (b) Salunke, J. K.; Wong, F. L.; Feron, K.; Manzhos, S.; Lo, M. F.; Shinde, D.; Patil, A.; Lee, C. S.; Roy, V. A. L.; Sonar, P.; Wadgaonkar, P. P. J. Mater. Chem. C 2016, 4, 1009. (c) Qu, B.; Chen, Z.; Liu, Y.; Cao, H.; Xu, S.; Cao, S.; Lan, Z.; Wang, Z.; Gong, Q. J. Phys. D: Appl. Phys. 2006, 39, 2680. (d) Zhu, Y.; Champion, R. D.; Jenekhe, S. A. Macromolecules 2006, 39, 8712.

(13) (a) Urselmann, D.; Deilhof, K.; Mayer, B.; Müller, T. J. J. Beilstein J. Org. Chem. 2016, 12, 2055. (b) Müller, T. J. J.; Franz, A. W. Barkschat (née Krämer) C. S.Sailer, M.; Meerholz, K.; Müller, D.; Colsmann, A.; Lemmer, U. Macromol. Symp. 2010, 287, 1. (c) Sailer, M.; Franz, A. W.; Müller, T. J. J. Chem. Eur J. 2008, 14, 2602.

(14) May, L.; Müller, T. J. J. Chem. Eur J. 2020, 26, 12111.

(15) May, L.; Müller, T. J. J. Molecules 2020, 25, 2180.

(16) (a) Dostert, C.; Müller, T. J. J. Org. Chem. Front. 2015, 2, 481. (b) Dostert, C.; Czajkowski, D.; Müller, T. J. J. Synlett 2014, 25, 371.

(17) Nau, J.; Schneeweis, A. P. W.; Müller, T. J. J. Mater. Chem. Front. 2020, 4, 621.

(18) Mori, S.; Barth, H. G. Size Exclusion Chromatography. Springer Science \& Business Media: Berlin, 2013.

(19) Netopilík, M.; Kratochvíl, P. Polymer 2003, 44, 3431.

(20) Meyer, T.; Ogermann, D.; Pankrath, A.; Kleinermanns, K.; Müller, T. J. J. J. Org. Chem. 2012, 77, 3704.

(21) Brutting, W.; Rieß, W. Phys. J. 2008, 7, 33.

(22) Krämer, C. S.; Zimmermann, T. J.; Sailer, M.; Müller, T. J. J. Synthesis 2002, 1163.

(23) Heiskanen, J. P.; Vivo, P.; Saari, N. M.; Hukka, T. I.; Kastinen, T.; Kaunisto, K.; Lemmetyinen, H. J.; Hormi, O. E. O. J. Org. Chem. 2016, 81, 1535.

(24) Han, F. S.; Higuchi, M.; Kurth, D. G. Org. Lett. 2007, 9, 559.

(25) Zanello, P. InFerrocenes. A. Togni, A.; Hayashi, T.VCH: Weinheim, 1995, 317. 